\title{
Dopaminergic System Genes in ADHD: Toward a Biological Hypothesis
}

\author{
Aiveen Kirley, M.R.C.Psych., Ziarih Hawi, M.Phil., Ph.D., Grainne Daly, B.A., M.Sc., \\ Mary McCarron, R.M.H.N., R.G.N., B.N.S., Celine Mullins, B.A. (Hons), Niamh Millar, B.Sc., \\ Irwin Waldman, B.S., Ph.D, Michael Fitzgerald, M.D., F.R.C.Psych., and \\ Michael Gill, M.D., M.R.C.Psych, F.T.C.D.
}

Converging evidence has implicated abnormalities of dopamine neurotransmission to the pathology of attention deficit hyperactivity disorder (ADHD). Several genetic association studies have been published, but so far, no DNA variants have been unequivocally demonstrated as contributing to ADHD susceptibility. Four dopamine related gene loci have been implicated, however: DAT1, $D R D 4, D B H$, and DRD5. Each of these may influence the liability of ADHD to a small degree. Notably, all are involved in signal transduction at the neuronal synapse. In this article, we investigate as candidate genes for ADHD, DNA polymorphisms at dopamine receptors, the dopamine transporter, and genes known to be involved in dopamine synthesis and metabolism. In a recent article, we confirmed the previously reported association of DAT1 (480bp allele) with ADHD and identified polymorphisms at two additional loci showing preferential transmission to $A D H D$ children of alleles at DRD5 (148bp allele) and at DBH (allele 2, Taq I polymorphism). Increased transmission of the $4 b p$ deletion in the untranslated exon 1 of the DOPA decarboxylase gene was also observed but was of marginal significance. Nonsignificant trends of association were found for TH (allele 2) and DRD2 (Ser-311). No preferential transmission of alleles to ADHD children was observed for polymorphisms at DRD1, DRD2 (Taq I), DRD3, DRD4, and COMT. Analyzing the data by sex of transmitting parent showed significant preferential paternal transmission of alleles at $\mathrm{TH}$ (allele 2) and a nonsignificant trend for paternal transmission for DRD2 (Ser-311). We attempt to put these findings together with what is known of the function of the particular proteins, and suggest working hypotheses.

[Neuropsychopharmacology 27:607-619, 2002] (C) 2002 American College of Neuropsychopharmacology. Published by Elsevier Science Inc.
KEY WORDS: Attention deficit hyperactivity disorder; Dopamine receptors; Candidate genes; Dopamine transporter; Haplotype-based haplotype relative risk; Transmission Disequilibrium Test; Imprinting

From the Department of Genetics and Psychiatry, Trinity College, Dublin, Ireland.

Address correspondence to: Dr. Aiveen Kirley, Department of Genetics and Psychiatry, Trinity Centre for Health Sciences, St James Hospital, Dublin 8, Ireland, Tel.: 353(1)-608-2465, E-mail: kirleya@ tcd.ie Received March 8, 2001; revised February 12, 2002; accepted February 20, 2002.

Online publication: 2/28/02 at www.acnp.org/citations/ Npp022802254.
Attention Deficit Hyperactivity Disorder (ADHD) is a common condition of childhood affecting 3-6\% of school age children worldwide (Barkley 1990), with males being affected three times more than females (Anderson et al. 1987; Baumgartel et al. 1995). Its core clinical features include excessive motor activity, impaired attention, and impulsivity. ADHD causes marked educational, social, and family difficulties for sufferers and their relatives. The condition is of early onset (usually before age 7) and tends to persist throughout childhood. Moreover, approximately $30-60 \%$ of children with ADHD have persisting psychopathology in adulthood (Gittelman et al. 1985; Weiss and Hechtman 1986; Barkley 1990; Swanson et al. 1998a). The exact etiology of ADHD is 
unknown, but a substantial genetic element exists. This has been demonstrated by family (Biederman et al. 1990, 1992; Faraone et al., 1992, 1994), twin (Thapar et al. 1995; Silberg et al. 1996; Levy et al. 1997), and adoption studies (Alberts-Corush et al. 1986; Cadoret and Stewart 1991). The heritability $\left(\mathrm{h}^{2}\right)$ of ADHD has been estimated to be .50-.98 (Gjone et al. 1996; Levy et al. 1997). The exact mode of transmission remains unknown. Segregation analyses (Morrison and Steward 1974; Deutsch et al. 1990, Faraone et al. 1992, Hess et al. 1995) have proposed models of inheritance from major gene effects through oligogenic to polygenic and multifactorial models, but the differences in statistical "fit" between multifactorial genetic models and single gene inheritance is modest. The multifactorial concept is consistent with ADHD's high population prevalence (2-7\%), high concordance in monozygotic twins $(68-81 \%)$, but modest recurrence risks to first-degree relatives.

Dysregulation in catecholamine neurotransmission is implicated in the pathophysiology of ADHD (Faraone and Biederman 2002). The dopaminergic neurotransmitter system has been most extensively studied. This article will focus mainly on its role in the etiology of ADHD. Evidence to support dopaminergic dysfunction in ADHD derives from three research areas: the neuropharmacology of stimulant medication (Zametkin and Rapoport 1987; Amara and Kuhar 1993), the behavior and biochemistry of animal models (Giros et al. 1996; Gainetdinov et al. 1999, Jaber et al. 1999, Russell 2000), and neuroimaging studies in ADHD adults (Dougherty et al. 1999, Krause et al. 2000, and Faraone and Biederman 2002). For this reason, many molecular genetic studies have focused on dopamine system genes.

The gene encoding the dopamine transporter, DAT1, was the initial candidate gene studied. This gene is of particular interest, as the transporter is the principal target for methylphenidate and other psychostimulant medication used to treat patients with ADHD (Volkow et al. 1998; Seeman and Madras 1998). Cook et al. (1995) reported an association between the $480 \mathrm{bp}$ DAT1 allele, one of the common alleles of a $40 \mathrm{bp}$ repeat situated in the $3^{\prime}$ untranslated region of the DAT1 gene which maps to 5p15.3 and ADHD. Since then, this finding has been replicated by our group (Gill et al. 1997; Daly et al. 1999), Waldman et al. (1998), and Curran et al. (2001) (in a UK sample), but not by others (Asherson et al. 1998; Palmer et al. 1999; Holmes et al. 2000; and Roman et al. 2001).

DRD4, the gene encoding the dopamine D4 receptor, has also attracted interest as a candidate gene. Studies by Benjamin et al. (1996) and Ebstein et al. (1996) have suggested an association between this gene and the personality trait of novelty seeking, a behavior also seen in ADHD. The dopamine D4 receptor mediates the postsynaptic action of dopamine. Furthermore, the 7 repeat allele of DRD4 mediates a blunted response to dopamine (Ashgari et al. 1995). To date, there have been 16 studies examining for association between the 7 repeat DRD4 polymorphism and ADHD, with positive results in many (LaHoste et al. 1996; Swanson et al. 1998b; Smalley et al. 1998; Rowe et al. 1998; Faraone et al. 1999; Muglia et al. 2000; Holmes et al. 2000; Sunohara et al. 2000; Tahir et al. 2000a; Mill et al. 2001), but not all (Castellanos et al. 1998; Comings et al. 1999; Eisenberg et al. 2000; Hawi et al. 2000a; Kotler et al. 2000; Todd et al. 2001) studies. A recent meta-analysis of DRD4 by Faraone et al. 2001 supported an overall association (albeit small) between DRD4 and ADHD. Case-control studies were more strongly significant $(\mathrm{OR}=1.9, p=.00000008)$ than familybased studies $(\mathrm{OR}=1.4, p=.02)$.

Other dopamine receptor genes have also been investigated as candidate genes in ADHD. We (Daly et al. 1999) reported association between the 148bp DRD5 allele and ADHD, using a family-based study design. Barr et al. (2000a) also reported this association $(p<.05)$, and Tahir et al. (2000a) found significant evidence of association between this polymorphism and a group of ADHD children who were methylphenidate responders. More recently, Payton et al. (2001) found a trend of association between the 148bp DRD5 allele and ADHD children.

Less is known about the role of the remaining dopamine receptor genes as potential susceptibility loci. Comings et al. (1991) found the A1 allele of the TaqI polymorphism of the $\mathrm{D} 2$ receptor gene to be more prevalent in patients with ADHD, compared with controls. Work by Rowe et al. (1999), however, did not show linkage or association between DRD2 and ADHD. Barr et al. (2000b) found no association between two DRD3 polymorphisms (located at exon I and intron 5) and ADHD.

Other studies have focused on genes involved in regulation of dopamine synthesis and metabolism. Eisenberg et al. (1999) reported association between a highactivity related Catechol-O-Methyltransferase (COMT) allele and ADHD. Three groups refuted this finding (Barr et al. 1999; Hawi et al. 2000b; Tahir et al. 2000b), and Eisenberg's group also failed to replicate the original finding (Manor et al. 2000). We (Daly et al. 1999) reported association at the A2 allele of the TaqI polymorphism of the gene (DBH) encoding the Dopamine Beta Hydroxylase enzyme. Interestingly, Comings et al. (1996) suggested that the DBH gene might have additive effects with DAT1 and DRD2 in a sample of Tourette syndrome patients with ADHD symptoms.

Other dopamine-related genes include tyrosine hydroxylase, dopa decarboxylase, and the monoamine oxidase genes on the $\mathrm{X}$-chromosome. The tyrosine hydroxylase enzyme is the rate-limiting step in the synthesis of catecholamines, and for this reason the gene $(\mathrm{TH})$ has been postulated as a candidate gene for ADHD and other neuropsychiatric disorders. Barr et al. (2000c) found no biased transmission of polymorphisms at the TH gene in a haplotype analysis of linkage between DRD4 and ADHD. DOPA decarboxylase is an enzyme involved in the syn- 
thesis of dopamine, noradrenaline, and serotonin. Functional imaging studies have shown altered DOPA decarboxylase activity in the midbrain of children with ADHD and in prefrontal areas in ADHD adults (Ernst et al. 1998; Ernst et al. 1999). There has been no published data, however, regarding the potential role of the DOPA gene as a susceptibility locus in ADHD. A Chinese study (Jiang et al. 2000) reported an association with the DXS7 locus on the $\mathrm{X}$ chromosome, a microsatellite marker closely linked to monoamine oxidase (MAO) genes that encode enzymes metabolising dopamine and other neurotransmitters. Subsequently, the same group (Jiang et al. 2001) found evidence for association between the MAO-A gene and ADHD. Our group (Lowe et al. 2001), however, found no evidence of linkage or association between ADHD and the DXS7 locus in an Irish sample.

Another candidate gene potentially related to dopamine transmission is the gene for the synaptic vesicle docking fusion protein, synaptosomal-associated protein of $25 \mathrm{kDa}$ (SNAP-25). This gene has also been implicated in the etiology of ADHD based on the mouse mutant strain coloboma (Wilson 2000). Mutations within the gene may affect the functions of synaptic vesicle fusion and neurotransmitter release. Recent studies by Barr et al. (2000d) and (Hawi et al. 2001) reported evidence for association with this gene but with different alleles in each sample.

Despite compelling evidence of a genetic basis for $\mathrm{ADHD}$, and findings of association replicated across several studies, the findings in ADHD are, to date, not definitive. If, as hypothesized, ADHD is a complex genetic disorder, with many susceptibility genes each of small effect (Suarez et al. 1998; Tannock 1998; Faraone and Biederman, in press), the pattern of results seen to date is to be expected. We will return to this in the Discussion section. It may be possible at this stage to examine the likely functional effects, if any, of the reported associations and consider how they might influence the biology of the dopaminergic system. Thus, we ask if the reported associations relate to each other functionally and point to a particular dopaminergic hypothesis. Agreement between the biological hypotheses and the genetic evidence increases the veracity of both.

In this article, we present an overview of our association study of dopamine system gene polymorphisms in ADHD. We will examine our findings and recent literature in this area and ask if the evidence supports a dopaminergic hypothesis in ADHD and if so, the likely nature of that hypothesis.

\section{MATERIALS AND METHODS}

One hundred and eighteen ADHD cases were recruited from child psychiatric clinics and schools in West County, Dublin, and from the Hyperactive and Atten- tion Deficit Children's Support Group of Ireland. Informed consent was obtained from all participants and patient confidentiality was maintained. The age range of the probands was between 4 and 14 years, with males accounting for $85 \%$. The families were $98 \%$ ethnically Irish. Approximately $80 \%$ of the children in this study with ADHD also met diagnostic criteria for other disorders such as Oppositional Defiant Disorder and Conduct Disorder. Details of diagnosis and clinical criteria can be found in Daly et al. (1999). Briefly, consensus diagnoses were made according to DSM-IV ADHD or UADD, either with or without comorbidity. These diagnoses were based on all available clinical information and the rating scales described below. The rating scales used were (1) the Child Behavior Checklist (CBCL), a widely based behavioral symptom measure, and the records of child behavior problems and social competencies as reported by parents; (2) the Connors Parents and Teachers Rating Scales, 48-item parent and 39-item teacher rating scales; (3) the Comprehensive Teachers Rating Scale (ACTeRS) which includes 24 items relevant to classroom behavior. The 25-item Wender-Utah rating scale (WURS) (Ward et al. 1993) was applied to all parents. This rating scale seeks retrospectively to make a diagnosis of ADHD during childhood. A cut-off score of 36 or higher is $96 \%$ sensitive and $96 \%$ specific for adults with ADHD as children (Ward et al. 1993). Familiality, for the purposes of the present study, was defined as the presence of one or more parents with a score on the WURS of $>36$.

\section{DNA Amplification}

DNA was extracted either from buccal cells as described in Gill et al. (1997) or from EDTA blood using the standard phenol chloroform procedure. PCR Primers sequence and amplification conditions used in this study are listed in Table 1. DAT1 and DRD4 alleles were detected using silver staining as described in Gill et al. (1997) and Hawi et al. (2000a). All genotypes were scored independently by two investigators who were blind to the identity of the sample or family relationships.

\section{Statistics}

In this study, we used a family based design to avoid any potential population stratification. In this method, which seeks to detect departure from Mendel's first law, the nontransmitted parental alleles are used as "controls" for comparison with transmitted parental alleles. For the Transmission Disequilibrium Test (Spielman and Ewens, 1996), alleles from heterozygous parents were identified as transmitted or not transmitted and tabulated. The $\chi^{2}$ test was used to assess the significance of the resulting tables, and odds ratios were calculated. Significance levels are presented without correction for multiple testing. For 
Table 1. PCR Primer Sequence and Amplification Conditions

\begin{tabular}{|c|c|c|}
\hline Marker & Sequence & Conditions \\
\hline DAT1 & $\begin{array}{l}\text { 5'TGTGGTGTAGGGAACGGCCTGAG3' } \\
\text { 5'CTTCCTGGAGGTCACGGCTCAAGG3' }\end{array}$ & Gill et al. 1997 \\
\hline $\mathrm{DBH}$ & $\begin{array}{l}\text { 5'CTGTATTTGGAACTTGGCATC3' } \\
\text { 5'AGGCATTTTACTACCCAGAGG3' }\end{array}$ & Daly et al. 1999 \\
\hline DRD1 & $\begin{array}{l}\text { 5'CTCTCGAAAGGAAGCCAAGA3' } \\
\text { 5'CGGCTCCGAAACGTTGAG3' }\end{array}$ & Cichon et al. 1996 \\
\hline DRD2(TaqI poly) & $\begin{array}{l}\text { 5'GGCTTAGAACCACCCAGAGT3' } \\
\text { 5'AGAGCAGTCAGGCTGGACAC3' }\end{array}$ & $\begin{array}{l}30 \text { cycles at } 95^{\circ} \mathrm{C} \text { for } 60 \mathrm{~S}, 64^{\circ} \mathrm{C} \\
\text { for } 60 \mathrm{~S} \text { and } 72^{\circ} \mathrm{C} \text { for } 60 \mathrm{~S}\end{array}$ \\
\hline DRD2(Ser-Cys) & $\begin{array}{l}\text { 5'ACCAGCTGACTCTCCCCGACCGGT3 } \\
\text { 5'GGAAGGACATGGCAGGGAATGGGAC3' }\end{array}$ & Spurlock et al. 1998 \\
\hline DRD3 & $\begin{array}{l}\text { 5'GCT CTATCTCCAACTCTCACA3' } \\
\text { 5'AAGTCTACTACACTCCAGGAT3' }\end{array}$ & Hawi et al. 1998 \\
\hline DRD4 & $\begin{array}{l}\text { 5' GCG ACTACG TGG TCTACT CG 3' } \\
5^{\prime} \text { AGG ACC CTC ATG GCC TTG 3' }\end{array}$ & Hawi et al. 2000a \\
\hline DRD5 & $\begin{array}{l}\text { 5'CGTGTATGATCCCTGCAG3' } \\
\text { 5'GCTCATGAGAAGAATGGAGTG3' }\end{array}$ & Daly et al. 1999 \\
\hline COMT & $\begin{array}{l}\text { 5' ACTGTGGCTACTCAGCTGTG 3' } \\
5^{\prime} \text { CCTTTTTCCAGGTCTGACAA 3' }\end{array}$ & Hawi et al. 2000b \\
\hline TH & $\begin{array}{l}\text { 5'GGCAAATAGGGGGCAAAA3' } \\
\text { 5'GGCTTCCGAGTGCAGGTC3' }\end{array}$ & $\begin{array}{l}30 \text { cycles at } 92^{\circ} \mathrm{C} \text { for } 30 \mathrm{~S}, 56^{\circ} \mathrm{C} \\
\text { for } 30 \mathrm{~S} \text { and } 72^{\circ} \mathrm{C} \text { for } 30 \mathrm{~S}\end{array}$ \\
\hline DOPA & $\begin{array}{l}\text { 5'GAGGGATGCTGCTCAGTAAA 3' } \\
\text { 5'ATCCAGAGAGCTGGACGC 3' }\end{array}$ & Speight et al. 2000 \\
\hline
\end{tabular}

comparison with our previous work (Gill et al. 1997; Daly et al. 1999), we calculated the haplotype-based haplotype relative risk (HHRR) statistic (Terwilliger and Ott 1992).

Further exploratory analyses were conducted by examining transmission of risk alleles by gender of transmitting parent and by family history. A transmission variable was created, coded 1 or 0 for transmission and nontransmission, respectively, of the risk allele from a heterozygous parent. This enabled exploration of the relationship between allelic transmission and the categorical variables of sex of transmitting parent and presence or absence of family history.

\section{RESULTS}

The associated alleles of dopamine and dopamine-related gene polymorphisms, their respective odds ratios and significance tests, and the numbers of alleles transmitted or not transmitted are presented in Tables 2 and 3. Significant preferential transmission of DAT1 $(480 \mathrm{bp}, 10$ repeat VNTR allele) (TDT $\left.\chi^{2}=4.57, p=.042\right)\left(\right.$ HHRR $\chi^{2}=7.5, p=$ $.0062)$, DBH (allele 2, TaqI) (TDT $\left.\chi^{2}=7.05, p=.01\right)(\mathrm{HHRR}$ $\left.\chi^{2}=9.0, p=.0027\right)$, and DRD5 (148bp dinucleotide repeat) $\left(\mathrm{TDT} \chi^{2}=7.35, p=.0088\right)\left(\mathrm{HHRR} \chi^{2}=16.36, p=.000052\right)$ were observed as previously reported. An increased frequency of transmission of DOPA-decarboxylase allele 1 was also observed which was of marginal statistical significance (TDT $\chi^{2}=4.67, p=.043$ ). The DRD2 Ser-311 and TH (allele 2 ) polymorphisms showed trends for association (TDT $\chi^{2}=1.67, p=.3$ ) and (TDT $\chi^{2}=1.23, p=$
.331), respectively. Analyses of DRD1, DRD3, DRD4, and COMT showed no significant differences between transmitted and non-transmitted alleles.

For alleles displaying association with ADHD, we then assessed whether there was a difference in the preferential transmission of risk alleles according to sex of transmitting parent or family history. We observed (in HHRR analyses) that for DAT1, DBH, and DRD2 (Ser-311), the transmission of the associated alleles appeared stronger when at least one of the parents was respectively diagnosed as ADHD. For DAT1, the relative risk in family history positive cases $(\mathrm{FH}+)$ was 1.50 compared with 1.33 in the family history negative cases (FH-). For $\mathrm{DBH}$, the

Table 2. Dopamine and Dopamine-Related Gene Polymorphisms in ADHD (HHRR)

\begin{tabular}{llllll}
\hline Marker & Associated allele & RR & OR & $\boldsymbol{\chi}^{2}$ & \multicolumn{1}{c}{$\mathbf{p}$} \\
\hline DAT1 & 480bp & 1.4 & 1.88 & 7.5 & 0.0062 \\
DBH & Allele 2(Taq1 poly) & 1.38 & 1.87 & 9.0 & 0.0027 \\
DRD1 & Allele 2 & 1.06 & 1.1 & 0.21 & 0.64 \\
DRD2 & Taq1 poly & 1.2 & 1.5 & 1.8 & 0.18 \\
DRD2 & Ser-Cys & 1.5 & 2.05 & 1.74 & 0.18 \\
DRD3 & Allele 1 & 1.07 & 1.15 & 0.34 & 0.56 \\
DRD4 & 7-repeat & 1.07 & 1.15 & 0.28 & 0.58 \\
DRD5 & 148bp & 1.57 & 2.52 & 16.36 & 0.000052 \\
COMT & Allele 2 & 1.06 & 1.12 & 0.29 & 0.59 \\
TH & Allele 2 & 1.1 & 1.21 & 0.89 & 0.34 \\
DOPA & Allele 1 & 1.24 & 1.52 & 2.7 & 0.1 \\
\hline
\end{tabular}

Associated allele(s) are those showing excess transmission. $\mathrm{RR}=$ relative risk; $\mathrm{OR}=$ odds ratio. 
Table 3. Dopamine and Dopamine-Related Gene Polymorphisms in ADHD (TDT)

\begin{tabular}{llccccr}
\hline Marker & Associated allele & OR & $\boldsymbol{\chi}^{\mathbf{2}}$ & $\mathbf{p}$ & $\mathbf{T}$ & $\mathbf{N T}$ \\
\hline DAT1 & 480bp & 1.63 & 4.57 & 0.042 & 49 & 30 \\
DBH & Allele 2 (Taq1 poly) & 1.88 & 7.05 & 0.01 & 49 & 26 \\
DRD1 & Allele 2 & 1.13 & 0.25 & 0.708 & 34 & 30 \\
DRD2 & Taq1 poly & 1.31 & 0.68 & 0.511 & 21 & 16 \\
DRD2 & Ser-Cys & 2.00 & 1.67 & 0.301 & 10 & 5 \\
DRD3 & Allele 1 & 1.07 & 0.07 & 0.893 & 29 & 27 \\
DRD4 & 7-repeat & 1.17 & 0.31 & 0.677 & 28 & 24 \\
DRD5 & 148bp & 1.79 & 7.35 & 0.0088 & 59 & 33 \\
COMT & Allele 2 & 1.21 & 0.67 & 0.482 & 40 & 33 \\
TH & Allele 2 & 1.36 & 1.23 & 0.331 & 30 & 22 \\
DOPA & Allele 1 & 2.00 & 4.67 & 0.043 & 28 & 14 \\
\hline
\end{tabular}

Associated allele(s) are those showing excess transmission. OR= odds ratio; $\mathrm{T}=$ transmitted alleles; $\mathrm{NT}=$ nontransmitted alleles

$\mathrm{FH}+\mathrm{RR}$ was 1.55 and the FH- RR was 1.26. For DRD2 (Ser-311), the FH+ RR was 2.32 and the FH- RR was 1. Formal statistical testing of transmissions according to family history (Table 4) showed, however, a trend for greater transmission of $\mathrm{DBH}$ to $\mathrm{FH}+$ cases than $\mathrm{FH}$ - cases $\left(\chi^{2}=1.56, p=.307\right)$ but no evidence of preferential transmission of DAT1 $\left(\chi^{2}=0.807, p=.49\right)$ or DRD2 to $\mathrm{FH}+$ cases compared with FH-cases (Table 4). TH also displayed a trend for greater transmission of the associated allele to $\mathrm{FH}+$ cases compared with FH- cases $\left(\chi^{2}=\right.$ $2.14, p=.27$ ). We also observed (in HHRR analyses) that transmission of the associated allele for DAT1 appeared to be stronger for fathers than for mothers (RR 1.73 and 1.33, respectively). For DBH and DRD5, the excess transmission of associated alleles appeared to be distributed equally between parents. For TH and DRD2, analysis by sex of parent also appeared to be stronger for fathers [TH: $(R R=1.47$ for fathers, $R R=0.86$ for mothers); DRD2: $(R R=4.15$ for fathers, $R R=0.83$ for mothers)]. Formal statistical comparison of transmissions

Table 4. TDT Analysis of Transmissions by Presence of Family History

\begin{tabular}{|c|c|c|c|c|c|c|c|c|}
\hline \multirow[b]{2}{*}{ Marker } & \multirow{2}{*}{$\begin{array}{l}\text { Associated } \\
\text { allele }\end{array}$} & \multicolumn{2}{|c|}{$\mathbf{F H}+$} & \multicolumn{2}{|c|}{ FH- } & \multirow[b]{2}{*}{$\chi^{2}$} & \multirow[b]{2}{*}{$\mathrm{p}$} & \multirow[b]{2}{*}{ OR (95\% CI) } \\
\hline & & $\mathbf{T}$ & NT & $\mathbf{T}$ & NT & & & \\
\hline DAT1 & 480bp & 16 & 5 & 12 & 7 & 0.807 & 0.494 & $1.87(0.47-7.35)$ \\
\hline $\mathrm{DBH}$ & Allele 2 & 13 & 4 & 19 & 9 & 1.56 & 0.307 & $2.44(0.59-10.04)$ \\
\hline DRD1 & Allele 2 & 14 & 9 & 7 & 8 & 0.741 & 0.509 & $1.78(0.48-6.62)$ \\
\hline DRD2 & Allele 2 & 5 & 7 & 9 & 4 & 1.924 & 0.238 & $0.32(0.06-1.64)$ \\
\hline DRD2 & Ser-Cys & 3 & 2 & 2 & 1 & 0.036 & 1.00 & $0.75(0.04-14.97)$ \\
\hline DRD3 & Allele 1 & 11 & 9 & 7 & 7 & 0.083 & 1.00 & $1.22(0.31-4.80)$ \\
\hline DRD4 & 7-repeat & 11 & 5 & 6 & 6 & 1.011 & 0.441 & $2.20(0.47-10.35)$ \\
\hline DRD5 & $148 \mathrm{bp}$ & 19 & 7 & 19 & 8 & 0.048 & 1.00 & $1.14(0.35-3.78)$ \\
\hline $\mathrm{TH}$ & Allele 2 & 9 & 6 & 5 & 10 & 2.14 & 0.27 & $3.0(0.68-13.31)$ \\
\hline DOPA & Allele 1 & 10 & 4 & 7 & 4 & 0.172 & 1.00 & $1.43(0.26-7.74)$ \\
\hline COMT & Allele 2 & 8 & 11 & 13 & 5 & 3.42 & 0.10 & $0.28(0.07-1.11)$ \\
\hline
\end{tabular}

Associated alleles are those showing excess transmission. $\mathrm{T}=$ transmitted; $\mathrm{NT}=$ nontransmitted; $\mathrm{OR}=$ odds ratio; $\mathrm{FH}+=$ family history positive; $\mathrm{FH}-=$ family history negative. from fathers versus mothers (Table 5) revealed significant preferential transmission from fathers of TH (allele 2) $\left(\chi^{2}=5.89, p=.015\right)$, and marginally significant transmission from fathers of DRD2 (Ser-311) $\left(\chi^{2}=3.26, p=\right.$ $.07)$. There was, however, no evidence of preferential transmission of DAT1 (480bp allele) from fathers to ADHD children $\left(\chi^{2}=0.701, p=.403\right)$.

\section{DISCUSSION}

We analyzed polymorphisms at the dopamine transporter gene (DAT1), dopamine receptors DRD1-DRD5, dopamine $\beta$ hydroxylase (DBH), Catechol-O-methyltransferase (COMT), tyrosine hydroxylase (TH), and DOPA-decarboxylase (DOPA) for possible association with ADHD in Irish nuclear families. We previously (Gill et al. 1997) confirmed a reported association at DAT1 (10 repeat allele) (Cook et al. 1995) and mapped two new susceptibility loci at DRD5 (148bp allele) and at DBH (allele 2, Taq I) (Daly et al. 1999). In addition to these findings, an increased transmission of allele 1 at DOPA (4bp insertion in the first untranslated exon) was observed but at a marginal level of significance. The DRD2 Ser311 allele also showed a nonsignificant trend of association with ADHD. Analyses by sex of transmitting parent indicate that, in our sample, the association of TH and to a lesser extent DRD2 (Ser-311) with ADHD is largely caused by the transmission of the paternal allele to the cases, suggesting the possibility of imprinting at these loci.

\section{Integrating Our Results with Existing Work}

Combining our findings with other studies suggests that DAT1 and DRD4 show the strongest evidence for association. Initial findings from studies examining DRD5 (Daly et al. 1999; Barr et al. 2000a; Tahir et al. 2000a; Payton et al. 2001) and DBH (Comings et al. 1996; Daly et al. 1999) are promising but require further replication. The interesting trends identified for DRD2 and DOPA have yet to be tested in other samples. Our finding of biased transmission for TH contradicts the negative findings of Barr et al. 2000(c). More studies are required to investigate the role of $\mathrm{TH}$ as a candidate gene in ADHD. We found no evidence of association for DRD1, DRD3, or COMT. Together with previous predominantly negative findings, we conclude that these genes are unlikely to play a major role in the pathophysiology of ADHD.

Our findings for TH and DRD2 in relation to parent of origin are interesting and suggest the possibility of imprinting in the inheritance of ADHD. The TH gene has been isolated and mapped to chromosome 11p15.5 (Craig et al. 1986; Moss et al. 1986). This region contains at least seven imprinted genes (Lee et al. 1999) which is intriguing, as imprinted genes tend to cluster. Also, the $5^{\prime}$ 
Table 5. TDT Analysis of Paternal and Maternal Transmissions

\begin{tabular}{|c|c|c|c|c|c|c|c|c|}
\hline \multirow[b]{2}{*}{ Marker } & \multirow{2}{*}{$\begin{array}{c}\text { Associated } \\
\text { allele }\end{array}$} & \multicolumn{2}{|c|}{$\begin{array}{c}\text { Paternal } \\
\text { transmissions }\end{array}$} & \multicolumn{2}{|c|}{$\begin{array}{c}\text { Maternal } \\
\text { transmissions }\end{array}$} & \multirow[b]{2}{*}{$\chi^{2}$} & \multirow[b]{2}{*}{$\mathrm{p}$} & \multirow[b]{2}{*}{ OR $(95 \% \mathrm{CI})$} \\
\hline & & $\mathbf{T}$ & NT & $\mathbf{T}$ & NT & & & \\
\hline DAT1 & $480 \mathrm{bp}$ & 25 & 11 & 16 & 11 & 0.701 & 0.403 & $1.56(0.55-4.44)$ \\
\hline $\mathrm{DBH}$ & Allele 2 & 19 & 9 & 25 & 12 & 0.001 & 0.980 & $1.01(0.36-2.90)$ \\
\hline DRD1 & Allele 2 & 11 & 10 & 13 & 10 & 0.076 & 0.78 & $0.85(0.26-2.78)$ \\
\hline DRD2 & Allele 2 & 10 & 8 & 7 & 4 & 0.183 & 0.67 & $0.71(0.15-3.33)$ \\
\hline DRD2 & Ser-Cys & 7 & 1 & 2 & 3 & 3.26 & 0.07 & $10.5(0.67-165.11)$ \\
\hline DRD3 & Allele 1 & 10 & 9 & 12 & 11 & 0.001 & 0.976 & $1.02(0.30-3.44)$ \\
\hline DRD4 & 7-repeat & 9 & 11 & 13 & 7 & 1.59 & 0.207 & $0.44(0.12-1.57)$ \\
\hline DRD5 & $148 \mathrm{bp}$ & 30 & 15 & 29 & 18 & 0.246 & 0.620 & $1.24(0.53-2.92)$ \\
\hline $\mathrm{TH}$ & Allele 2 & 20 & 7 & 10 & 15 & 5.89 & 0.015 & $4.29(1.32-13.88)$ \\
\hline DOPA & Allele 1 & 12 & 4 & 15 & 9 & 0.676 & 0.411 & $1.8(0.44-7.31)$ \\
\hline COMT & Allele 2 & 19 & 12 & 16 & 16 & 0.809 & 0.368 & $1.58(0.58-4.31)$ \\
\hline
\end{tabular}

Associated alleles are those showing excess transmission. $\mathrm{T}=$ transmitted; $\mathrm{NT}=$ nontransmitted; $\mathrm{OR}=\mathrm{odds}$ ratio.

flanking region of the $\mathrm{TH}$ gene is known to be methylated (Okuse et al. 1997), methylation being a putative process involved in imprinting. In addition, DRD2 also maps to chromosome 11 (11q22-23) (Grandy et al. 1989), a region containing the imprinted PGL gene is known to cause hereditary paragangliomas in humans (van Schothorst et al. 1996). To date, few others have examined their data by sex of transmitting parent and, therefore, the findings are speculative and require replication. Tahir et al. (2000a) found no association between parent of origin and transmission of DRD4 (7-repeat variant) and DRD5 (148bp variant), the latter in agreement with our data. The same study found no evidence of association between DRD4 and DRD5 and family history. In our study, for DBH and $\mathrm{TH}$, transmission of the associated alleles was stronger for families with at least one parent who was retrospectively diagnosed as having ADHD using a score on the WURS $>36$. This data, although nonsignificant, suggests that variations at these loci may confer risk, particularly for a familial subtype of ADHD. As with the data suggesting imprinting, our data relating to family history and our findings on $\mathrm{DBH}$ and $\mathrm{TH}$ require replication.

In contrast with other studies, we found no association between the 7-repeat DRD4 allele and ADHD in our sample. As with the data published for the DAT1 gene, there are a number of possible reasons for apparent inconsistency of results. Small sample size limits power in individual studies. Negative findings from such studies may result in publication bias. Differences in methodological assessment of ADHD cases, referral bias, IQ, degree of comorbidity, environmental factors (e.g., socio-economic group) and ethnic variation in study populations may be further reasons for inconsistent findings. Another likely reason for conflicting results is etiological heterogeneity. Difficulties in defining the phenotype in ADHD have been highlighted (Thapar et al. 1999; Todd 2000). A major question is whether ADHD is a categorical disorder or might be better described in terms of dimensions of inattention and hyperactivity. A further question is the likely etiological model, genetic or otherwise, of comorbid conditions such as conduct disorder and depression. Another possible factor in the pattern of conflicting results is the fact that the "associated" genes in all studies to date confer genetic susceptibility to ADHD with small relative risks/odds ratios (typically in the region 1.5-2). Individual studies have insufficient power, therefore, to detect minor gene effects, and careful meta-analysis of all available data will be required. This strategy has proven to be informative in the case of the 7-repeat DRD4 variant. Faraone et al. (2001) concluded that in a meta-analysis of 22 studies, a small but highly significant association exists at DRD4. Future directions for molecular genetic studies in ADHD include increasing sample size and power by collaboration, coordinating usage of data collection instruments to allow for comparison between research groups, the use of meta-analysis, and a move toward better characterization of the ADHD phenotype.

\section{Evidence Supporting a Dopamine Hypothesis in ADHD and the Contribution of Molecular Genetic Studies}

To date, the evidence supporting the role of dopamine in the pathophysiology of ADHD comes from studies in wide-ranging areas. Key findings from these studies are summarized below. Stimulant medication such as methylphenidate, which effectively treat ADHD symptoms, are known to inhibit the dopamine transporter (Amara and Kuhar 1993), block the reuptake of dopamine and noradrenaline into the presynaptic neuron, and increase the release of these monoamines into the extraneuronal space (Elia et al. 1990). The mecha- 
nism of action of methylphenidate is consistent with a hypodopaminergic hypothesis of ADHD. Brain lesions in mice (Garfinkel and Wender 1989) and monkeys (Schneider and Roeltgen 1993) that create behaviors similar to those seen in ADHD implicate dopaminergic pathways. The spontaneously hypertensive rat (SHR) has also been used as an animal model of ADHD because of the SHR's locomotor hyperactivity and impaired discriminative performance. Studies on the SHR implicate dopaminergic and noradrenergic systems (Russell et al. 1995; de Villiers et al. 1995; Papa et al. 1998; King et al. 2000) but do not support a simple theory of altered dopamine neurotransmission in ADHD. Structural brain imaging studies have shown abnormalities in the frontal lobe and subcortical structures (globus pallidus, caudate, corpus callosum), regions known to be rich in dopamine neurotransmission and important in the control of attention and response to organization (Lou et al. 1990; Zametkin et al. 1990; Rubia et al. 1997). The most consistent findings from functional neuroimaging studies in humans are hypoactivity of frontal cortex and subcortical structures, usually on the right side (Faraone and Biederman, in press). Recently, Dougherty et al. (1999) investigated dopamine transporter density in vivo and found a $70 \%$ increase in ADHD adults compared with healthy controls. This finding also lends support to a functional hypodopaminergic hypothesis of ADHD.

\section{The Contribution of Molecular Genetic Studies to a Dopamine Hypothesis for ADHD}

It is clearly important to attempt to investigate the relationship between genotype, dopamine neurotransmission, and behaviors observed in ADHD. It appears, however, that no unitary theory of dopamine transmission in ADHD is yet plausible based on current evidence. With regard to DAT1, its protein, the dopamine transporter, is the site of action of methylphenidate and other related medications. Blocking the transporter consequently increases the amount of extracellular dopamine in the neuronal synapse and possibly increases the inhibitory influence of frontal cortical activity on subcortical structures. It has been recently suggested that the $480 \mathrm{bp}$ DAT1 (10 repeat allele) allele may be associated with a hyperactive dopamine transporter (Swanson et al. 2000). A functional brain imaging study (Heinz et al. 2000) demonstrated that abstinent alcoholics heterozygous for the 10 repeat DAT1 allele had less $(22 \%)$ putamen dopamine transporter availability compared with those who were homozygous. As the 10 repeat allele is considered to be the high-risk allele in ADHD, it is possible that individuals with this allele have increased transporter density, which may lead to a depletion of dopamine from critical synaptic regions. This hypothesis received further support from a recent neuroimaging study that demonstrated increased binding of a specific dopamine transporter ligand in the striatal regions in adult patients with ADHD compared with normal controls (Krause et al. 2000). What is not yet known is whether the stronger signal represents stronger binding of the ligand to the transporter or a larger number of transporter molecules. As the 10 repeat (480bp) DAT1 allele maps to the $3^{\prime}$ untranslated region of the gene, it is itself unlikely to change the structure or function of the dopamine transporter protein. Two recent studies suggest, however, that certain variants of the 40bp DAT1 VNTR can function as transcriptional regulators. Michaelhaugh et al. (2001) found that the 9 repeat DAT1 allele enhanced transcription in dopamine neurons in neonatal rat midbrain and in an immortalized dopaminergic cell line. Fuke et al. (2001) showed that the 10 repeat DAT1 allele had the greatest positive effect on gene expression in human DNA using the luciferase reporter system. Thus, the 3' UTR VNTR of DAT1 may have direct functional relevance in the control of the expression of the gene or in the stability of its mRNA. Alternatively, the observed association may indicate linkage disequilibrium with another variant at the coding or the regulatory regions of DAT1 or closely mapped locus. Barr et al. (2001) found significant evidence for biased transmission of a haplotype containing the DAT1 480bp allele, and polymorphisms at intron 9 and exon 9 of the DAT1 gene. Further analysis of the DAT1 gene is necessary to identify other possible variants within the gene that contribute to the increased susceptibility to ADHD. The role of DAT1 in animal models of ADHD has also been examined. Animal studies have shown that DAT1 knockout mice have increased extracellular dopamine but reduced striatal dopamine and tyrosine hydroxylase activity (Jaber et al. 1999) and may suggest that feedback mechanisms lead to reduced striatal dopamine. This is particularly interesting as DAT1 knockout mice have hyperactivity as part of their phenotype (Giros et al. 1996; Gainetdinov et al. 1999), and neuroimaging studies suggest frontostriatal dysfunction in ADHD patients (reviewed by Tannock 1998). Overall, the evidence for DAT1 suggests relative hypodopaminergic transmission in critical areas such as the striatum and the possible influence of excess dopamine neurotransmission from higher cortical areas.

Biological evidence supporting the possible role of other genes in a dopaminergic theory of ADHD is less than that for DAT1. The functional relevance of the 7 repeat allele at DRD4, another important candidate gene, is unclear but may encode a D4 receptor that is subsensitive to dopamine (Ashgari et al. 1995). Thus, the 7 repeat DRD4 allele may contribute to reduced dopamine transmission in ADHD and fit in with the hypodopaminergic hypothesis described above for DAT1.

The $\mathrm{DBH}$ gene is a quantitative trait locus for $\mathrm{DBH}$ enzyme activity. The Taq 1 polymorphism tested in this 
study is known to be in significant linkage disequilibrium (Daly et al. 1999) with polymorphisms (in promoter and exon 2 regions) associated with reduced DBH enzyme activity (Cubells et al. 1998). In experimental animals with decreased serum $\mathrm{DBH}$, reduced conversion of dopamine to noradrenaline lessens negative feedback on tyrosine hydroxylase (Anden et al. 1973; Axelrod and Weinshilboum 1972). The net result is excessive production of dopamine in these animals who are observed to display hyperactivity, aggression, self-stimulation, and stereotypic movements (Randrup and Scheel-Kruger 1996). The limited evidence presented for the $\mathrm{DBH}$ gene therefore suggests hyperdopaminergic transmission in ADHD, in contrast with the evidence above for DAT1 and DRD4.

The 148bp DRD5 polymorphism maps outside the coding region of the DRD5 gene (Sherrington et al. 1993), and therefore it is unlikely to alter DRD5 protein structure, or receptor binding and signaling. The functional relevance of DRD5 to dopamine neurotransmission in ADHD is, to date, unknown.

Functional brain imaging studies (Ernst et al. 1998; Ernst et al. 1999) have reported increased DOPA decarboxylase activity in the midbrains of ADHD children and decreased activity in prefrontal regions in ADHD adults. The authors hypothesized that the increased subcortical activity was the primary abnormality. Its origin may have been functional (e.g., upregulation of DOPA decarboxylase secondary to midbrain dopaminergic deficit) or structural (e.g., increased number of synapses caused by an adaptive response to dopaminergic imbalance). The authors hypothesized that the reduced prefrontal DOPA decarboxylase activity was secondary and resulted from an interaction of the primary midbrain dopamine deficit with the processes of neural maturation and adaptation. Thus, we can speculate that the evidence for the DOPA gene also contributes to a hypodopaminergic theory in ADHD.

Absence of the DRD2 gene in mice leads to significantly reduced spontaneous movements, suggesting that DRD2 plays a role in the regulation of activity levels (Baik et al. 1995; Comings et al. 1991). Mice without DRD2 genes also show decreased striatal dopamine transporter functioning (Dickinson et al. 1999). In contrast, DRD1 and DRD3 knockout mice demonstrate hyperactivity as part of their phenotype. The biological and genetic data for the role of these genes in ADHD is uncertain.

As stated previously, a definitive theory of dopamine neurotransmission in ADHD is not yet possible. Overall evidence from genetic studies indicates that the candidate genes receiving most support are DAT1 and DRD4. DBH, DRD5, and TH are other genes that may also cause susceptibility to the disorder. The evidence we have presented for DAT1 supports a theory of decreased dopamine neurotransmission in ADHD. In particular, findings from a number of neuroimaging and animal studies (Heinz et al. 2000; Krause et al. 2000; Jaber et al. 1999; Tannock et al. 1998) suggest that hy- podopaminergic function in the striatum may be involved in mediating the symptoms and neurocognitive abnormalities displayed in ADHD. There are fewer studies examining the role of the other genes, and their contribution to the neurobiology of ADHD is unclear. The evidence presented for DRD4 and DOPA may also support a theory of reduced dopamine transmission. Conversely, animal studies of DBH suggest a possible role in increasing dopamine transmission in ADHD. There is insufficient evidence regarding the functional role of DRD5 in ADHD. Animal studies of other receptor genes such as DRD1, DRD2, and DRD3 may indicate their role in activity regulation. Overall, it could be speculated that biochemical pathways are likely to be complicated with multiple feedback and protective mechanisms (as suggested by animal studies), and that dopamine deficit and excess, individually or in combination, may contribute to ADHD depending on the dopamine receptor and the brain region affected (Castellanos 1997 and Swanson et al. 1998c).

It is undoubtedly too simplistic to assume that the genetic etiology of ADHD is caused by abnormal dopamine transmission alone. Indeed, there is considerable evidence implicating other neurotransmitter systems in ADHD, in particular noradrenergic and serotoninergic systems. It is beyond the scope of this article to discuss their contribution. Also, as the heritability $\left(h^{2}\right)$ of ADHD is less than 1.0, it is likely that environmental factors also play a role in the causation and outcome of ADHD.

Exciting new directions in this field of research are emerging, for example, the move toward dissection of the ADHD phenotype in quantitative-trait based studies and also, the preliminary findings regarding parent of origin effects for DRD2 and TH as described in this article. The combination of small gene effects and modest sample sizes will make it unlikely that genetic association methods alone will prove causation. Despite the lack of a single unified hypothesis in ADHD, which combines existing evidence for susceptibility DNA variants with known or proposed biological function, it will remain important to continue to integrate findings from all sources. Such work should enable us to further our understanding of this complex and challenging disorder.

\section{ACKNOWLEDGMENTS}

This work was generously supported by the Health Research Board, Dublin,; The Wellcome Trust (AK and ZH); and the Hyperactive and Attention Disorder Group Ireland. We would also like to thank the families that participated in the study.

\section{REFERENCES}

Alberts -Corush J, Firestone P, Goodman JT (1986): Attention and impulsivity characteristics of the biological and 
adoptive parents of hyperactive and normal control children. Am J Orthopsychiatry 56:413-423

Amara S, Kuhar M (1993): Neurotransmitter transporters: recent progress. Ann Rev Neurosci 16:73-93

Anden ME, Atack CV, Svensen TH (1973): Release of dopamine from central noradrenaline and dopamine nerves by a dopamine $\beta$-hydroxylase inhibitor. J Neural Transm 34:93-100

Anderson, JC, Williams S., McGee R., Silva PA (1987): DSMIII-R disorders in preadolescent children: prevalence in a large sample from the general population. Arch Gen Psychiatry 44:69-76

Asherson P, Virdee V, Curran S, Ebersole L, Freeman B, Craig I, Simonson E, Eley T, Plomin R, Taylor E (1998): Association study of DSM IV attention -deficit hyperactivity disorder (ADHD) and monoamine pathway genes. Am J Med Genet Neuropsychiatr Genet 81:549

Ashgari V, Sanyal S, Buchwaldt S (1995): Modulation of intracellular cyclic AMP levels by different human dopamine D4 receptor variants. J Neurochem 65:1157-1165

Axelrod J, Weinshilboum RM (1972): Catecholamines. N Engl J Med 287:237-242

Baik JH, Picetti R, Saiardi A, Thiriet G, Dierich A, Depaulis A, Le Meur M, Borrelli E (1995): Parkinsonian-like locomotor impairment in mice lacking dopamine D2 receptors. Nature 377(6548):424-428

Barkley RA (1990): Attention Deficit Hyperactivity Disorder: A Handbook for Diagnosis and Treatment. New York, Guilford

Barr CL, Wigg K, Malone M, Schachar R, Tannock R, Roberts W, Kennedy JL (1999): Linkage study of catechol-O-methyltransferase and attention-deficit hyperactivity disorder. Am J Med Genet 88(6):710-713

Barr CL, Wigg KG, Feng Y, Zai G, Malone M, Roberts W, Schachar R, Tannock R, Kennedy JL (2000a): Attentiondeficit hyperactivity disorder and the gene for the dopamine D5 receptor. Mol Psychiatry 5:548-551

Barr CL, Wigg KG, Wu J, Zai C, Bloom S, Tannock R, Roberts W, Malone M, Schachar R, Kennedy JL (2000b): Linkage study of two polymorphisms at the dopamine D3 receptor gene and attention-deficit hyperactivity disorder. Am J Med Genet Neuropsychiatr Genetics 96: 114-117

Barr CL, Wigg KG, Bloom S, Schachar R, Tannock R, Roberts W, Malone M, Kennedy JL (2000c): Further evidence from haplotype analysis for linkage of the dopamine D4 receptor gene and attention-deficit hyperactivity disorder. Am J Med Genet 96(3):262-267

Barr CL, Feng Y, Wigg K, Roberts W, Malone M, Schachar R, Tannock R, Kennedy JL (2000d): Identification of DNA variants in the SNAP-25 gene and linkage study of these polymorphisms and attention-deficit hyperactivity disorder. Mol Psychiatry 5:405-409

Barr CL, Xu C, Kroft J, Feng Y, Wigg K, Zai G, Tannock R, Schacher R, Malone M, Roberts W, Nothen MM, Grunhage F, Vandenburgh DJ, Uhl G, Sunohara G, King N, Kennedy JL (2001): Haplotype study of three polymorphisms at the dopamine transporter locus confirm linkage to attention-deficit/hyperactivity disorder. Biol Psychiatry 49:333-339
Baumgartel A, Wolraich ML, Dietrich M (1995): Comparison of diagnostic criteria for attention deficit disorders in a German elementary school sample. J Am Acad of Child Adolesc Psychiatry 34: 629-638

Benjamin J, Patterson C, Greenberg BD (1996): Population and familial association between the D4 dopamine receptor gene and measures of novelty seeking. Nat Genet 12:81-84

Biederman J, Faraone SV, Keenan K, Knee D, Tsuang MT (1990): Family-genetic and psychosocial risk factors in DSM-III attention deficit disorder. J Am Acad Child Adolesc Psychiatry 29(4):526-533

Biederman J, Faraone SV, Keenan K, Benjamin J, Krifcher B, Moore C, Sprich-Buckminster S, Ugaglia K, Jellinek MS, Steingard R, Spencer T, Norman D, Kolodny R, Kraus I, Perrin J, Keller MB, Tsuang MT (1992): Further evidence for family-genetic risk factors in attention deficit hyperactivity disorder patterns of comorbidity in probands and relatives in psychiatrically and paediatrically referred samples. Arch Gen Psychiatry 49:728-738

Cadoret RJ, Stewart MA (1991): An adoption study of ADH/D and aggression and their relationship to adult antisocial personality. Comp Psychiatry 32:73-82

Castellanos FX (1997): Toward a pathophysiology of attentiondeficit/hyperactivity disorder. Clin Paediatr 36:381-393

Castellanos FX, Lau E, Tayebi N, Lee P, Long RE, Giedd JN, Sharp W, Marsh WL, Walter JM, Hamburger SD, Ginns EL, Rapoport JL, Sidransky E (1998): Lack of association between a dopamine-4 receptor polymorphism and attention deficit hyperactivity disorder: genetic and brain morphometric analyses. Mol Psychiatry 3:431-434

Cichon S, Nothen MM, Stober G, Schroers R, Albus M, Maier W, Rietschel M, Korner J, Weigelt B, Franzek E, Wildenauer D, Fimmers R, Propping P (1996): Systematic screening for mutations in the 5 '-regulatory region of the human dopamine D1 receptor (DRD1) gene in patients with schizophrenia and bipolar affective disorder. Am J Med Genet 67(4):424-428

Comings DE, Comings BG, Muhleman D, Dietz G, Shahbahrami B, Tast D, Kocsis P, Baumgarten R, Kovacs BW, Levy DL, Smith M, Borison RL, Evans DD, Klein DN, MacMurray J, Tosk JM, Sverd J, Gysin R, Flanagan SD (1991): The dopamine D2 receptor locus as a modifying gene in neuropsychiatric disorders. JAMA 266(13): 1793-1800

Comings DE, Wu S, Chiu C, Ring RH, Gade R, Ahn C, MacMurray JP, Dietz G, Muhleman D (1996): Polygenic inheritance of Tourette syndrome, stuttering, attention deficit hyperactivity, conduct and oppositional defiant disorder: the additive and subtractive effect of the three dopaminergic genes-DRD2, DBH, and DAT1. Am J Med Genet 67:264-288

Comings DE, Gonzalez N, Wu S, Gade R, Muhleman D, Saucier G, Johnson P, Verde R, Rosenthal RJ, Lesieur HR, Rugle LJ, Miller WB, MacMurray JP (1999): Studies of the 48 bp repeat polymorphism of the DRD4 gene in impulsive, compulsive, addictive behaviors: Tourette syndrome, ADHD, pathological gambling, and substance abuse. Am J Med Genet 88(4):358-368

Cook EH, Stein MA, Krasowski MD, Cox NJ, Olkon DM, Kieffer JE, Leventhal BL (1995): Association of attention-deficit disorder and the dopamine transporter gene. Am J Hum Genet 56:993-998 
Craig SP, Buckle VJ, Lamouroux A, Mallet J, Craig I (1986): Localization of the human tyrosine hydroxylase gene to 11p15: gene duplication and evolution of metabolic pathways. Cytogenet Cell Genet 42(1-2):29-32

Cubells JF, van Kammen DP, Kelley ME, Anderson GM, O'Connor DT, Price LH, Malison R, Rao PA, Kobayashi K, Nagatsu T, Gelernter J (1998): Dopamine $\beta$-hydroxylase: two polymorphisms in linkage disequilibrium at the structural gene DBH associate with biochemical phenotypic variation. Hum Genet 102:533-540

Curran S, Mill J, Tahir E, Kent L, Richards S, Gould A, Huckett L, Sharp J, Batten C, Fernando S, Ozbay F, Yazgan Y, Simonoff E, Thompson M, Taylor E, Asherson P (2001): Association study of a dopamine transporter polymorphism and attention deficit hyperactivity disorder in UK and Turkish samples. Mol Psychiatry 6(4):425-428

Daly G, Hawi Z, Fitzgerald M, Gill M (1999): Mapping susceptibility loci in attention deficit hyperactivity disorder: Preferential transmission of parental alleles at DAT1, DBH and DRD5 to affected children. Mol Psychiatry 4:192-196

Deutsch CK, Mattyse S, Swanson JM, Farkas LG (1990): Genetic latent structure analysis of dysmorphology in attention deficit disorder. J Am Acad Child Adolesc Psychiatry 29(2):189-194

de Villiers AS, Russell VA, Sagvolden T, Searson T, Searson A, Jaffer A, Taljaard JJ (1995): Alpha 2-adrenoceptor mediated inhibition of $[3 \mathrm{H}]$ dopamine release from nucleus accumbens slices and monoamine levels in a rat model for attention-deficit hyperactivity disorder. Neurochem Res 20(4):427-433

Dickinson SD, Sabeti J, Larson GA, Giardina K, Rubinstein M, Kelly MA, Grandy DK, Low MJ, Gerhardt GA, Zahniser NR (1999): Dopamine D2 receptor-deficient mice exhibit decreased dopamine transporter function but no changes in dopamine release in dorsal striatum. J Neurochem 72(1):148-156

Dougherty DD, Bonab AA, Spencer TJ, Rauch SL, Madras BK, Fischman AJ (1999): Dopamine transporter density in patients with attention deficit hyperactivity disorder. Lancet 354 (9196):2132-2133

Elia J, Borcherding BG, Potter WZ, Mefford IN, Rapoport JL, Keysor CS (1990): Stimulant drug treatment of hyperactivity: biochemical correlates. Clin Pharmacol Ther 48:57-66

Eisenberg J, Mei-Tal G, Steinberg A, Tartakovsky E, Zohar A, Gritsenko I, Nemanov L, Ebstein RP (1999): A haplotype relative risk study of catechol-O-methyltransferase (COMT) and attention deficit hyperactivity disorder (ADHD): association of the high-enzyme activity Val allele with ADHD impulsive-hyperactive phenotype. Am J Med Genet 88(5):497-502

Eisenberg J, Zohar A, Mei-Tal G (2000): A haplotype relative risk study of the dopamine D4 (DRD4) exon III repeat polymorphism and attention deficit hyperactivity disorder (ADHD). Am J Med Genet 96:258-261

Ebstein J, Zohar A, Mei-Tal G (1996): Dopamine D4 receptor (D4DR) exon III polymorphism associated with the human personality trait of novelty seeking. Nat Genet 12:78-80

Ernst M, Zametkin AJ, Matochik JA, Jons PH, Cohen RM (1998): DOPA decarboxylase activity in attention deficit hyperactivity disorder adults. A (Fluorine-18) fluoro- dopa positron emission tomographic study. J Neurosci 18(15):5901-5907

Ernst M, Zametkin AJ, Matochik JA, Pascualvaca D, Jons PH, Cohen RM (1999): High midbrain (18F)DOPA accumulation in children with attention deficit hyperactivity disorder. Am J Psychiatry 156(8):1209-1215

Faraone S, Biederman J, Chen WJ, Krifcher B, Keenan K, Moore C, Sprich S, Tsuang M (1992): Segregation analysis of attention deficit hyperactivity disorder: evidence for single gene transmission. Psychiat Genet 2:257-275

Faraone SV, Biederman J, Milberger S (1994): An exploratory study of ADHD among second-degree relatives of ADHD children. Biol Psychiatry 35:398-402

Faraone SV, Biederman J, Weiffenbach B, Keith T, Chu MP, Weaver A, Spencer TJ, Wilens TE, Frazier J, Cleves M, Sakai J (1999): Dopamine D4 gene 7-repeat allele and attention deficit hyperactivity disorder. Am J Psychiatry 156(5):768-770

Faraone SV, Doyle AE, Mick E, Biederman J (2001): Metaanalysis of the association between the dopamine D4 7-repeat allele and attention deficit hyperactivity disorder. Am J Psychiatry 158(7):1052-1057

Faraone SV, Biederman J (2002): Pathophysiology of Attention Deficit Hyperactivity Disorder. In: Davis K, Charney D, Coyle JT, Nemeroff C (eds), ACNP's Fifth Generation of Progress-Version 2. New York, Lipponcott, Williams, and Wilkens

Fuke S, Suo S, Takahashi N, Koike H, Sasagawa N, Ishiura S (2001): The VNTR polymorphism of the human dopamine transporter (DAT1) gene affects gene expression. The Pharmacogenomics Journal 1:152-156

Gainetdinov RR, Wetsel WC, Jones SR, Levin ED, Jaber M, Caron MG (1999): Role of serotonin in the paradoxical calming effect of psychostimulants on hyperactivity. Science 83(5400):397-401

Garfinkel BD, Wender PH (1989): Attention deficit hyperactivity disorder. In Kaplan HI, Sadock BJ (eds), Comprehensive Textbook of Psychiatry. Baltimore, Williams and Wilkins, pp.1831

Gill M, Daly G, Heron S, Hawi Z, Fitzgerald M (1997): Confirmation of association between attention deficit hyperactivity disorder and a dopamine transporter polymorphism. Mol Psychiatry 2:311-313

Giros B, Jaber M, Jones S, Wightman RM, Caron M (1996): Hyperlocomotion and indifference to cocaine and amphetamine in mice lacking the dopamine transporter. Nature 379:606-612

Gittelman R, Mannuzza S, Shenker R, Bonagura N (1985): Hyperactive boys almost grown up. I. Psychiatric status. Arch Gen Psychiatry 42:937-947

Gjone H, Stevenson J, Sundet JM (1996): Genetic influence on parent-reported attention related problems in Norwegian general population twin sample. J Am Acad Child and Adoles Psychiatry 35:588-596

Grandy DK, Litt M, Allen L (1989): The human dopamine D2 receptor gene is located on chromosome 11 at q22-q23 and identified a Taq 1 RFLP. Am J Hum Genet 45:778-785

Hawi Z, McCabe U, Straub RE, O'Neill A, Kendler KS, Walsh D, Gill M (1998): Examination of new and reported data of the DRD3/MscI polymorphism: no 
support for the proposed association with schizophrenia. Mol Psychiatry 3(2):150-155

Hawi Z, McCarron M, Kirley A, Fitzgerald M, Gill M (2000a): No association of the dopamine DRD4 receptor with attention deficit hyperactivity disorder (ADHD) in the Irish population. Am J Med Genet Neuropsychiatr Genet 96:268-272

Hawi Z, Millar N, Daly G, Fitzgerald M, Gill M (2000b): No association between Catechol-O-methyltransferase (COMT) gene polymorphism and attention deficit hyperactivity disorder (ADHD) in an Irish sample. Am J Med Genet Neuropsychiatr Genet 96:282-284

Hawi Z, Brophy K, Kirley A, Fitzgerald M, Gill M (2001): Synaptosomal-associated protein 25 (SNAP-25) and attention deficit hyperactivity disorder (ADHD): evidence of linkage and association in the Irish population. Mol Psychiatry (In Press)

Hess EJ, Rogan PK, Domoto M, Tinker DE, Ladda RL, Ramer JC (1995): Absence of linkage of apparently single gene mediated ADHD with the human syntenic region of the mouse mutant Coloboma. Am J Med Genet 60(6):573-579

Heinz A, Goldman D, Jones DW, Palmour R, Hommer D, Gorey JG, Lee KS, Linnoila M, Weinberger DR (2000): Genotype influences In Vivo dopamine transporter availability in human striatum. Neuropsychopharmacology 22(2):133-139

Holmes J, Payton A, Barrett JH, Hever T, Fitzpatrick H, Trumper AL, Harrington R, McGuffin P, Owen M, Ollier W, Worthington J, Thapar A (2000): Family-based and case control association study of the dopamine D4 receptor gene and dopamine transporter gene in attention deficit hyperactivity disorder. Mol Psychiatry 5:523-530

Jaber M, Dumartin B, Sagne C, Haycock JW, Roubert C, Giros B, Bloch B, Caron MG (1999): Differential regulation of tyrosine hydroxylase in the basal ganglia of mice lacking the dopamine transporter. Eur J Neurosci 11(10):3499-3511

Jiang S, Xin R, Wu X, Lin S, Qian Y, Ren D, Tang G, Wang D (2000): Association between attention deficit hyperactivity disorder and the DXS7 locus. Am J Med Genet 96(3):289-292

Jiang S, Xin R, Qian Y, Lin S, Li F, Wu X, Wang D, Tang G, Jiang K (2001): Study of susceptibility loci located within Xp11 in attention deficit hyperactivity disorder. Zhonghua Yi Xue Za Zhi 18(3):169-172

King JA, Barkley RA, Delville Y, Ferris CF (2000): Early androgen treatment decreases cognitive function and catecholamine innervation in an animal model of ADHD. Behav Brain Res 107(1-2):35-43.

Kotler M, Manor I, Sever Y, Eisenberg J, Cohen H, Ebstein RP, Tyano S (2000): Failure to replicate an excess of the long dopamine D4 exon III repeat polymorphism in ADHD in a family-based study. Am J Med Genet 96(3):278-281

Krause KL, Dresel SH, Krause J, Kung HF, Tatsch K (2000): Increased striatal dopamine transporter in adult patients with attention deficit hyperactivity disorder: effects of methylphenidate as measured by single photon emission computed tomography. Neurosci Lett 285:107-110

LaHoste GL, Swanson JM, Wigal SB, Glabe C, Wigal T, King
N, Kennedy JL (1996): Dopamine D4 receptor gene polymorphism is associated with attention deficit hyperactivity disorder. Mol Psychiatry 1:121-124

Lee MP, Brandenburg S, Landes GM, Adams M, Miller G, Feinberg AP (1999): Two novel genes in the centre of the 11 15 imprinted domain escape genomic imprinting. Hum Mol Genet 8(4):683-690

Levy F, Hat DA, McStephen M, Wood C (1997): Attention deficit hyperactivity disorder: a category or continuum? Genetic analysis of a large-scale twin study. J Am Acad Child and Adoles Psychiatry 36:737-744

Lou HC, Henriksen L, Bruhn P (1990): Focal cerebral dysfunction in developmental learning disabilities. Lancet 335:8-11

Lowe N, Hawi Z, Fitzgerald M, Gill M (2001): Letter to the editor: no evidence of linkage or association between ADHD and DXS7 locus in Irish population. Am J Med Genet 105:394-95.

Manor I, Kotler M, Sever Y, Eisenberg J, Cohen H, Ebstein RP, Tyano S (2000): Failure to replicate an association between the catechol-O-methyltransferase polymorphism and attention deficit hyperactivity disorder in a second, independently recruited Israeli cohort. Am J Med Genet 96(6):858-860

Michaelhaugh SK, Fiskerstrand C, Lovejoy E, Bannon MJ, Quinn JP (2001): The dopamine transport gene (SLC6A3) variable number of tandem repeats domain enhances transcription in dopamine neurons. J Neurochem 79:1033-1038

Mill J, Curran S, Kent L, Richards S, Gould A, Virdee A, Huckett L, Sharp J, Batten C, Fernando S, Simonoff E, Thompson M, Zhao J, Sham P, Taylor E, Asherson P (2001): Attention deficit hyperactivity disorder (ADHD) and the dopamine D4 receptor gene: evidence of association but no linkage in a UK sample. Mol Psychiatry 6(4):440-444

Morrison JR, Steward MA (1974): Bilateral inheritance as evidence for polygenicity in the hyperactive child syndrome. J Nerv Ment Dis 158:226-228

Moss PAH, Davies KE, Boni C, Mallet J, Reeders ST (1986): Linkage of tyrosine hydroxylase to four other markers on the short arm of chromosome 11. Nucleic Acids Res 14:9927-9932

Muglia P, Jain U, Macciardi F, Kennedy JL (2000): Adult attention deficit hyperactivity disorder and the dopamine D4 receptor gene. Am J Med Genet 96:273-277

Okuse K, Matsuoka I, Kurihara K (1997): Tissue-specific methylation occurs in the essential promoter element of the tyrosine hydroxylase gene. Brain Res Mol Brain Res 46(1-2):197-207.

Palmer CG, Bailey JN, Ramsey C, Cantwell D, Sinsheimer JS, Del'Homme M, McGough J, Woodward JA, Asarnow R, Asarnow J, Nelson S, Smalley SL (1999): No evidence of linkage or linkage disequilibrium between DAT1 and attention deficit hyperactivity disorder in a large sample. Psychiatr Genet 9(3):157-160

Papa M, Berger DF, Sagvolden T, Sergeant JA, Sadile AG (1998): A quantitative cytochrome oxidase mapping study, cross-regional and neurobehavioural correlations in the anterior forebrain of an animal model of attention deficit hyperactivity disorder. Behav Brain Res 94(1):197-211 
Payton A, Holmes J, Barrett JH, Hever T, Fitzpatrick H, Trumper AL, Harrington R, McGuffin P, O'Donovan M, Owen M, Ollier W, Worthington J, Thapar A (2001): Examining for association between candidate gene polymorphisms in the dopamine pathway and attention-deficit hyperactivity disorder: a family-based study. Am J Med Genet 105(5):464-70

Randrup A, Scheel-Kruger J. (1966): Dietyldithiocarbanate and stereotyped behaviour. J Pharmacol 18(11):752

Roman T, Schmitz M, Polanczyk G, Eizirik M, Rohde LA, Hutz MH (2001): Attention-deficit hyperactivity disorder: a study of association with both the dopamine transporter gene and the dopamine D4 receptor gene. Am J Med Genet 105(5):471-478

Rowe DC, Stever C, Giendinghagen LN, Gard JMC, Cleveland $\mathrm{HH}$, Terris ST, Mohr JH, Shermans S, Abramowitz A, Waldman ID (1998): Dopamine DRD4 receptor polymorphism and attention deficit hyperactivity disorder. Mol Psychiatry 3:419-426

Rowe DC, den Oord EJ, Stever C, Giedinghagen LN, Gard JM, Cleveland HH, Gilson M, Terris ST, Mohr JH, Sherman S, Abramowitz A, Waldman ID (1999): The DRD2 Taq 1 polymorphism and symptoms of attention deficit hyperactivity disorder. Mol Psychiatry 4(6):580-586

Rubia K, Overmeyer S, Taylor E, Bullmore E, Brammer M, Williams S, Simmons A, Andrew C (1997): Inhibitory control of hyperactive adolescents in fMRI. In Toga AW, Frackowiak RSJ, Mazziotta JC (eds), Neuroimage. Third International Conference on Functional Mapping of the Human Brain (May 19-23, Copenhagen, Denmark). New York, Academic Press

Russell V, de Villiers A, Sagvolden T, Lamm M, Taljaard J (1995): Altered dopaminergic function in the prefrontal cortex, nucleus accumbens and caudate-putamen of an animal model of attention-deficit hyperactivity disorder: the spontaneously hypertensive rat. Brain Res 676(2):343-351

Russell VA (2000): The nucleus accumbens motor-limbic interface of the spontaneously hypertensive rat as studied in vitro by the superfusion slice technique. Neurosci Biobehav Rev 24(1):133-136

Schneider JS, Roeltgen DP (1993): Delayed matching-tosample, object retrieval, and discrimination reversal deficits in chronic low dose MPTP-treated monkeys. Brain Res 615(2):351-354

Seeman P, Madras BK (1998): Anti-hyperactivity medication: methylphenidate and amphetamine. Mol Psychiatry 3:386-396

Sherrington R, Mankoo B, Dixon M, Curtis D, Kalsi G, Melmer G, Gurling H (1993): Microsatellite polymorphisms for chromosome 5 bands q11.2-q13.3. Hum Hered 43:197-202

Silberg J, Rutter M, Meyer J, Maes H, Hewitt J, Simonoff E, Pickles A, Loeber R, Eaves L (1996): Genetic and environmental influences on the covariation between hyperactivity and conduct disturbance in juvenile twins. J Child Psychol Psychiatry 37:803-816

Smalley SL, Bailey JN, Palmer CG, Cantwell DP, McGough JJ, Del'Homme MA, Asarnow JR, Woodward JA, Ramsey C, Nelson SF (1998): Evidence that the dopamine D4 receptor is a susceptibility gene in attention deficit. Mol Psychiatry 3:427-430
Speight G, Turic D, Austin J, Hoogendoorn B, Cardno AG, Jones L, Murphy KC, Sanders R, McCarthy G, Jones I, McCandless F, McGuffin P, Craddock N, Owen MJ, Buckland P, O'Donovan MC (2000): Comparative sequencing and association studies of aromatic L-amino acid decarboxylase in schizophrenia and bipolar disorder. Mol Psychiatry 5(3):327-331

Spielman RS, Ewens WJ (1996): The TDT and other familybased tests for linkage disequilibrium and association. Am J Hum Gen 59:983-989

Spurlock G, Williams J, McGuffin P, Aschauer HN, Lenzinger E, Fuchs K, Sieghart WC, Meszaros K, Fathi N, Laurent C, Mallet J, Macciardi F, Pedrini S, Gill M, Hawi Z, Gibson S, Jazin EE, Yang HT, Adolfsson R, Pato CN, Dourado AM, Owen MJ(1998): European Multicentre Association Study of Schizophrenia: a study of the DRD2 Ser311Cys and DRD3 Ser9Gly polymorphisms. Am J Med Genet 81(1):24-28.

Sunohara GA, Roberts W, Malone M, Schachar RJ, Tannock R, Basile VS, Wigal T, Wigal SB, Schuck S, Moriarty J, Swanson JM, Kennedy JL, Barr CL (2000): Linkage of the dopamine D4 receptor gene and attention-deficit/ hyperactivity disorder. J Am Acad Child Adolesc Psychiatry 39(12):1537-1542

Suarez BK, Hampe CL, Van Eerdewegh P (1998): Problems of replicating linkage claims in psychiatry. In Gershon ES, Cloninger CR, Barrett JE (eds), Genetic Approaches in Mental Disorders. Washington, DC: American Psychiatric Press, pp 23-46

Swanson JM, Sergeant JA, Taylor E, Sonuga-Barke EJS, Jensen PS, Cantwell DP (1998a): Attention-deficit hyperactivity disorder and hyperkinetic disorder. Lancet 351:429-433.

Swanson JM, Sunohara GA, Kennedy JL, Regino R, Fineberg E, Wigal T, Lerner M, Williams L, LaHoste GJ, Wigal S (1998b): Association of the dopamine receptor D4 (DRD4) gene with a refined phenotype of attention deficit hyperactivity disorder (ADHD): a family-based approach. Mol Psychiatry 3(1):38-41.

Swanson J, Castellanos FX, Murias M, LaHoste G, Kennedy J (1998c): Cognitive neuroscience of attention deficit hyperactivity disorder and hyperkinetic disorder. Cur Opin Neurobiol 8:263-271

Swanson JM, Flodman P, Kennedy J, Spence MA, Moyzis R, Schuck S, Murias M, Moriarity J, Barr C, Smith M, Posner M (2000): Dopamine genes and ADHD. Neurosci Biobehav Rev 24:21-25

Tahir E, Yazgan Y, Cirakoglu B, Ozbay F, Waldman I, Asherson PJ (2000a): Association and linkage of DRD4 and DRD5 with attention deficit hyperactivity disorder (ADHD) in a sample of Turkish children. Mol Psychiatry 5(4):396-404

Tahir E, Curran S, Yazgan Y, Ozbay F, Cirakoglu B, Asherson PJ (2000b): No association between low- and highactivity catecholamine-methyl-transferase (COMT) and attention deficit hyperactivity disorder (ADHD) in a sample of Turkish children. Am J Med Genet 96:285-288

Tannock R (1998): Attention deficit hyperactivity disorder: advances in cognitive, neurobiological and genetic research. J Child Psychol Psychiatr 39(1):65-99

Terwilliger JD, Ott J (1992): A haplotype-based 'haplotype relative risk' approach to detecting allelic transmissions. Hum Hered 42:337-346 
Thapar A, Hervas A, McGuffin P (1995): Childhood hyperactivity scores are highly heritable and show sibling competition effects: twin study evidence. Behav Genet 25:537-544

Thapar A, Holmes J, Poulton K, Harrington R. (1999): Genetic basis of attention deficit and hyperactivity. Br J Psychiatry 174:105-11.

Todd RD (2000): Genetics of attention deficit/hyperactivity disorder: are we ready for molecular genetic studies? Am J Med Genet 96(3):241-243

Todd RD, Neuman RJ, Lobos EA, Jong YJ, Reich W, Heath AC (2001): Lack of association of dopamine D4 receptor gene polymorphisms with ADHD subtypes in a population sample of twins. Am J Med Genet 105(5):432-438

van Schothorst EM, Jansen JC, Bardoel AF, van der Mey AG, James MJ, Sobol H, Weissenbach J, van Ommen GJ, Cornelisse CJ, Devilee P (1996): Confinement of PGL, an imprinted gene causing hereditary paragangliomas, to a 2-cM imterval on 11q22-q23 and exclusion of DRD2 and NCAM as candidate genes. Eur J Hum Genet 4(5):267-73.

Volkow ND, Wang GJ, Fowler JS, Gatley SJ, Logan J, Ding YS, Hitzemann R, Pappas N (1998): Dopamine transporter occupancies in the human brain induced by therapeutic doses of oral methylphenidate. Am J Psychiatry 155: 1325-1331
Waldman ID, Rowe DC, Abramowitz A, Kozel ST, Mohr JH, Sherman SL, Cleveland HH, Sanders ML, Gard JMC, Stever C (1998): Association and linkage of the dopamine transporter gene and attention-deficit hyperactivity disorder in children: heterogeneity owing to diagnostic subtype and severity. Am J Hum Genet 63:1767-1776

Ward MF, Wender PH, Reimherr FW (1993): The Wender Utah Rating Scale: An aid in the retrospective diagnosis of childhood attention deficit hyperactivity disorder. Am J Psychiatry 150(6):885-890

Weiss G, Hechtman LT (1986): Hyperactive Children Grown Up. New York, Guildford

Wilson MC (2000): Coloboma mouse mutant as an animal model of hyperkinesis and attention deficit hyperactivity disorder. Neurosci Behav Rev 24:51-55

Zametkin AJ, Rapoport JL (1987): Noradrenergic hypothesis of attention deficit disorder with hyperactivity: A critical review. In Meltzer HY (ed), Psychopharmacology: The Third Generation of Progress. New York, Raven Press, pp 837-842

Zametkin AJ, Nordahl TE, Gross J, King CA, Semple WE, Rumsey J, Hamberger MA, Cohen RM (1990): Cerebral glucose metabolism in adults with hyperactivity of childhood onset. N Engl J Med 323:1361-1366 